\title{
FISSURELLIDAE IN JAPAN (2)
}

$\operatorname{AUTHOR}(\mathrm{S})$ :

Habe, Tadashige

CITATION:

Habe, Tadashige. FISSURELLIDAE IN JAPAN (2). PUBLICATIONS OF THE SETO MARINE BIOLOGICAL LABORATORY 1953, 3(1): 33-50

ISSUE DATE:

1953-07-30

URL:

http://hdl.handle.net/2433/174462

RIGHT: 


\title{
FISSUREIIIDAE IN JAPAN (2)*
}

\author{
TADAShige HABE \\ Zoological Institute and Seto Marine Biological Laboratory, \\ Kyoto University
}

\section{With Plate II}

This is the second of a series of papers dealing with the Fissurellid fauna of Japan. Part I (HABE, Illust. Cat. Jap. Shells, 17, pp. 109-120, 1951) contained the genera Macroschisma, Scutus, Zeidora, Rimula, Fissurisepta and Puncturella. The part given here reports on the species of the genera Emarginula, Laeviemarginula, Emarginella, Tugali, Tugalina, Montfortula and Montfortia.

\section{Genus Emarginula LAMARCK 1801}

1801 Emarginula LAMARCK, Syst. Anim. s. Vert., p. 69.

1810 Emarginulus MONTFORT, Conchyl. Syst., p. 74.

Type species: Emarginula conica Lamarck (monotypy).

\section{Emarginula fujitai n. sp.}

(P1. II, Figs. 32, 33)

1929 Emarginula foveolata FuJrTA, Venus, 1 (3), p. 88, pl. 3, fig. 10 and textfig. 1, non SCHEPMAN 1908.

1929 Emarginula foveolata KURODA, l.c., p. 93.

Shell rather large, attaining up to $25 \mathrm{~mm}$. in length, deeply sculptured, white, highly conical, the height being about four-fifths of the shell length; anterior slope convex and posterior slope concave, immediately below the apex, then extending downward in a straight line to the margin; apical whorl small, smooth and polished, close to a little below the summit, bent down posteriorly and situated at the posterior third of the length of the shell; anal fasciole narrow,

* Contributions from the Seto Marine Biological Laboratory, No. 200.

Publ. Seto Mar. Biol. Lab., III (1), 1953. (Article 3) 
with numerous arched lamellae; fissure rather short and about one-sixth the the length of the anterior slope; sculpture consists of about 30 strong primary ribs, radiating from the apex to the margin and secondary ribs alternating with them; numerous concentric cords dividing the spaces between the ribs into deeply excavated coarse square pits, thus giving the surface a foveolate appearance; interior of the shell chalky white; margin crenulated by the terminations of the ribs.

Height $14.8 \mathrm{~mm}$, length of aperture $21.5 \mathrm{~mm}$, breadth of aperture $16.0 \mathrm{~mm}$. (figured type specimen deposited in the Geological Institute of Kyoto University).

Height $18.2 \mathrm{~mm}$, length of aperture $25.6 \mathrm{~mm}$, breadth of aperture $18.7 \mathrm{~mm}$. (examined specimen collected from Wakayama Pref., Honshu by Mr. Akibumi TERAMACHI).

Type locality: Tateyama Bay, Bōsō Peninsula, Honshu.

Distribution: Tateyama Bay and off Wakayama Pref., Honshu and Tosa Bay, Shikoku.

Fossil occurrence: Moeshima in the Kagoshima Bay, Kyushu (Pleistocene).

Remarks: This species was erroneously recorded as E. foveolata ScHEPMAN from Tateyama Bay by Mr. Tadashi Furita, to whom the specific name is dedicated. In the former the shell is more highly conical and the aperture elliptical in shape, not distinctly narrowed anteriorly.

\section{Emarginula hataii n. sp.}

(P1. II, Figs. 13, 20)

1940 Emarginula foveolata NomURA et HATAT, Saito Ho-on Kai Mus. Res. Bull. 19, p. 59, non SchePMAN 1908.

Shell medium in size, reaching $13 \mathrm{~mm}$. in length, solid, milky white, the height being about $60 \%$ of the shell length; aperture elongate elliptical in shape; anterior slope strongly, convexly arched and posterior slope concave immediately below the apex, more weakly concave downward; apical whorls one and one half in number, and place strongly down the shell and situated at the posterior end; anal fasciole narrow, distantly crossed by transverse lamellae; fissure long and narrow, slightly shorter than one half of the anterior slope; radial sculpture consists of 21 to 27 widely spaced primary ribs, and in addition to them, there occur secondary ribs between each two of them; concentric sculpture consists of widely spaced cords forming small nodules, where they intersect the ribs; these cords divide the spaces between the ribs into coarse and deep square pits; two radial ribs, a little more highly elevated than the rest, border the fasciole 
and the fissure; margin crenulated by the terminations of ribs; interior of shell chalky white.

Height $8.0 \mathrm{~mm}$., length of aperture $12.8 \mathrm{~mm}$, breadth of aperture $9.0 \mathrm{~mm}$. (figured type specimen).

Height $8.2 \mathrm{~mm}$, length of aperture $12.8 \mathrm{~mm}$., breadth of aperture $8.5 \mathrm{~mm}$. (paratype specimen).

Height $6.3 \mathrm{~mm}$., length of aperture $11.4 \mathrm{~mm}$., breadth of aperture $8.3 \mathrm{~mm}$. (examined specimen from off Tugaru Beninsula, Aomori Pref., Honshu; Sôyômaru station No. $646,123 \mathrm{~m}$. in depth).

Height $6.8 \mathrm{~mm}$, length of aperture $12.4 \mathrm{~mm}$., breadth $8.6 \mathrm{~mm}$. examined specimen from off Noto Peninsula, Honshu, about 100 fathoms in depth).

Height $6.6 \mathrm{~mm}$., length of aperture $12.6 \mathrm{~mm}$., breadth of aperture $8.6 \mathrm{~mm}$. (examined specimen from off Noto Peninsula, Hoshu).

Type locality: Kyuroku-jima, Aomori Pref., Honshu $(210 \mathrm{~m}$. and $150 \mathrm{~m}$. in depth).

Distribution: Japan Sea (off Noto Peninsula to off Tugaru Peninsula).

Remarks: This new species was reported as $E$. foveolata ScHEPMAN from Kyuroku-jima, Aomori Pref., Honshu by Sitihei Nomura and Kotora Hatar, but both species are quite different in shape. E. fujitai, also reported as E. foveolata by Tadashi Fujita from Tateyama Bay, Honshu, differs from this new species in the larger and higher conical shell with the pointed apex and the short fissure. I take pleasure in naming this for Dr. Kotora HATAT.

\section{Emarginula fragilis YOKOYAMA.}

(P1. II, Figs. 21, 22)

1920 Emarginula fragilis YoKoYAMA, Jour. Coll. Sci. Imp. Univ. Tokyo, 39 (6), p. 98, p1. 6, fig. 10 .

1929 Emarginula fragilis FuJITA, Venus, 1 (3). p. 88, pl. 3, fig. 9 and textfig. 2.

1929 Emarginula fragilis KURODA, l.c., 1 (3), p. 94.

Height $10.5 \mathrm{~mm}$., length of aperture $16 \mathrm{~mm}$., breath of aperture $11.5 \mathrm{~mm}$. (figured specimen collected from off Wakayama Pref., Honshu).

Height $10.1 \mathrm{~mm}$, length of aperture $17.7 \mathrm{~mm}$, breadth of aperture $12.0 \mathrm{~mm}$. (examined specimen collected by Mr. Akibumi Teramachi from off Wakayama Pref., Honshu.).

Height $10.6 \mathrm{~mm}$, length of aperture $16.7 \mathrm{~mm}$., breadth of aperture $11.4 \mathrm{~mm}$. (examined specimen collected from Sagami Bay, Honsht by Mr. Ryosuke KAWAMURA).

Height $7.8 \mathrm{~mm}$., length of aperture $13.8 \mathrm{~mm}$, breadth of aperture $9.8 \mathrm{~mm}$. 
(examined specimen collected from Sagami Bay).

Type locality: Harashita, Shimo-miyata, Kanagawa Pref., Honshu.

Distribution: Sagami Bay and off Wakayama Pref., Honshu and Tosa Bay, Shikoku.

Fossil occurrence: Type locality (Pleistocene).

\section{Emarginula regia n. sp.}

(Pl. IT, Figs. 30, 31)

Shell large, exceeding $33 \mathrm{~mm}$. in length and $20 \mathrm{~mm}$. in height, conical, its height being two-thirds of the shell length, colour ashy grey, probably due to the long stay in the mud; aperture broadly ovate; anterior slope straight or feebly convex, posterior slope somewhat concave below the apex, extending downward in a straight line to the margin; apical whorls small, smooth, coiled down a little below the summit and situated at about the posterior third of the shell length; anal fasciole narrow, formed by very closely set transverse lamellae ; fissure also narrow, one-fourth of the length of the anterior slope; sculpture compact, consists of numerous closely set radial ribs; at the apical area there are about 40 primary ribs, but below numerous finer ribs are intercalated between them, thus the total number of ribs attaining more than 100; also numerous concentric lamellae intersect the radiating ribs, giving scaly aspects on the point of intersection of ribs; margin crenulated by the terminations of the ribs.

Height $19.3 \mathrm{~mm}$., length of aperture $32.9 \mathrm{~mm}$., breadth of aperture $27.0 \mathrm{~mm}$. (figured type specimen collected by Mr. Akibumi Teramachi).

Height $21.2 \mathrm{~mm}$, length of aperture $36.3 \mathrm{~mm}$, breadth of aperture $29.5 \mathrm{~mm}$. (paratype specimen).

Type locality: Tosa Bay, Shikoku (about 100 fathoms in depth).

Remarks: Emarginula hawaiiensis DALL is the nearest ally of this new species in the general appearances, but may be easily distinguished from this in having the apex situated more posteriorly.

\section{Emarginula crassicostata SOWERBY}

1863 Emarginula crassicostata Sowerby, Thes. Conch., 3, p. 214, pl. 246, figs. 41, 42.

1873 Emarginula crassicosiata SoWERBY, Conch. Icon., 19, Emarginula, pl. 6, fig. 38.

1890 Emarginula crassicostata PILSBRY. Man. Conch., 12, p. 259, p1. 29, figs. 30_32.

1913 Emarginula crassicostata THIELE, Conch, Cab., 2 (4a), p. 68, pl. 8, fig. 10.

1935 Emarginula crassicostata OTukA, Bull. Earthq. Res. Inst., 13 (4), p. 846, pl. 53, figs. $21 \mathrm{a}, \mathrm{b}$. 
1951 Emarginula crassicostata Is. TAKI, HIRASE's Handb. Illust. Shells, pl. 63, fig. 1.

Height $5.2 \mathrm{~mm}$., length of aperture $10.6 \mathrm{~mm}$., breadth of aperture $7.7 \mathrm{~mm}$. (examined specimen collected by Mr. Akibumi Teramachi from Noto Peninsula, Honshu).

Height $5.7 \mathrm{~mm}$., length of aperture $11.5 \mathrm{~mm}$., breadth of aperture $8.1 \mathrm{~mm}$. (examined specimen collected by Mr. Masatoyo Okamoro from Kanezaki, Munakata-gun, Fukuoka Pref., Kyushu).

Type locality : unknown.

Distribution: Kyushu; Shikoku and Honshu.

Fossil occurrence: The Oti Graben in Southern Noto Peninsula, Honshu (Pleistocene).

Remarks: This is the commonest species in our coast.

\section{Emarginula hosoyai n. sp.}

Shell medium in size, about $11 \mathrm{~mm}$. in length, solid, pale cream yellow in colour, height being about $60 \%$ of the length: aperture elliptical; anterior slope convex; posterior slope slightly concave or straight; apical whorls one and one half in number and are reduced to a small hook; the position of apical whorls close to a little below the summit and situated at the posterior end; anal fasciole narrow, provided with transverse lamellae; fissure narrow, its length being one-fifth of the anterior slope; sculpture consists of about 40 radiating ribs from the apex; below secondary ribs appear between each two of the primary ribs; numerous concentric cords divide the spaces between ribs into small square pits.

Height $8.2 \mathrm{~mm}$., length of aperture $13.6 \mathrm{~mm}$, breadth of aperture $10.1 \mathrm{~mm}$. (type specimen collected by Mr. Akibumi Teramachi).

Height $4.5 \mathrm{~mm}$., length of aperture $8.6 \mathrm{~mm}$, breadth of aperture $6.0 \mathrm{~mm}$. (paratype).

Height $4.8 \mathrm{~mm}$., length of aperture $8.9 \mathrm{~mm}$., breadth of aperture $6.5 \mathrm{~mm}$. (examined specimen collected by Mr. Kakujiro Hosoya from the Sagami Bay, 50 fathoms in depth).

Height $5.1 \mathrm{~mm}$., length of aperture $8.9 \mathrm{~mm}$, breadth of aperture $6.6 \mathrm{~mm}$. (examined specimen from the Sagami Bay).

Type locality: Tosa Bay, Shikoku (about 70 fathoms in depth).

Distribution: Sagami Bay and off Wakayama Pref., Honshu and Tosa Bay, Shikoku.

Remarks: This new species differs quite sharply from $E$. hataii to which it 
appears to be nearest in relationship; the former has more densely set square pits on the cream yellow shell. This species is named in honour of Mr. Kakujiro Hosoya, who is a famous collector of shells of Sagami Bay.

\section{Emarginula teramachii n. sp.}

(Pl. II, Figs. 14, 23)

Shell medium in size, reaching about $10 \mathrm{~mm}$. in length; dull white, probably due to its existence in the mud, highly conical; the height being about $70 \%$ of the shell length; anterior slope gently convex and posterior slope concave immediately below the apex, then extending downward in a straight line to the margin; aperture elliptical in sharpe; apical whorls small, smooth and polished, hooked down posteriorly and situated at the posterior end; anal fasciole long and narrow; fissure narrow, shorter than one-third of the length of the anterior slope; sculpture consists of about 15 primary radial cords and at a short distance from the apex, secondary ribs appear between each two of the primary ribs; forming nodules on the point of intersection, dividing the spaces between ribs into deeply excavated square pits, giving the shell a lattice-like appearance; margin crenulated by the terminations of the ribs.

Height $6.7 \mathrm{~mm}$., length of aperture $9.5 \mathrm{~mm}$., breadth of aperture $7.0 \mathrm{~mm}$. (the largest paratype specimen colleced by Mr. Akibumi TERAMACHI).

Height $6.2 \mathrm{~mm}$, length of aperture $8.6 \mathrm{~mm}$, breadth of aperture $6.2 \mathrm{~mm}$. (figured type specimen).

Height $5.6 \mathrm{~mm}$., length of aperture $7.5 \mathrm{~mm}$., breadth of aperture $5.5 \mathrm{~mm}$. (paratype specimen).

Type locality: Tosa Bay, Shikoku (about 70 fathoms).

Remarks: Emarginula adamsiana SOWERBY somewhat relates to this new species in its shape, but has the sctilpture on the shell decidedly coarser than in the latter. Emarginula choristes Dall from off Gwajajima, south of Kyushu, is another allied one, but it has a larger shell with the sculpture differing from that of this new species. The specific name is dedicated to Mr. Akibumi Teramachir who is an expert of the shell collecting in Japan.

\section{Emarginula choristes DALL}

1925 Emarginula choristes Dall, Proc. U. S. Nat. Mus., 66 (17), p. 16, pl. 26, figs. 1, 4.

Height $18 \mathrm{~mm}$., length of aperture $17 \mathrm{~mm}$, breadth of aperture $12 \mathrm{~mm}$. Type locality: Gwajajima, south of Kyushu (361 fathoms in depth). 


\section{Emarginula adamsiana SOWERBY}

1863 Emarginula adamsiana SOWERBY, Thes. Conch., 3, p. 214, pl. 246, figs. 27, 28.

1873 Emarginula adamsiana SowERBY. Conch. Icon., 19, Emarginula, pl. 4, fig. 29.

1890 Emarginula adamsiana PILSBRY. Man. Conch., 12. p. 260, pl. 28, fig. 32.

1913 Emarginula adamsiana THIELE, Conch. Cab., 2 (4a), p. 63, pl. 7, fig. 13.

Height $3.0 \mathrm{~mm}$, length of aperture $6.0 \mathrm{~mm}$., breadth of aperture $4.25 \mathrm{~mm}$. (after THIELE).

Type locality: Japan.

Emarginula tosaensis n. sp.

Shell rather large for the genus, attaining $18 \mathrm{~mm}$. in length, rather solid, pale yellow in colour, sometimes ornamented with broad radial patterns, the height being about $50 \%$ of the length of shell; aperture elliptical in shape; anterior slope long, gently convex and the posterior slope short, straight except for the part below the apex which is concave; apical whorls small and smooth, coiled down the summit and situated near the posterior end; anal fasciole long and narrow; the fissure also narrow, but rather short, about one-fourth of the anterior slope ; sculpture rather compact, consisting of about 30 radial ribs, below secondary ribs appear between each two of the primary ribs; numerous concentric cords which are a little lamellae on the point of intersection resulting numerous small square pits; margin denticulate; interior of the shell white and polished.

Height $8.7 \mathrm{~mm}$., length of aperture $18.0 \mathrm{~mm}$., breadth of aperture $12.8 \mathrm{~mm}$. (type specimen collected by $\mathrm{Mr}$. Akibumi Teramachi).

Height $8.0 \mathrm{~mm}$., length of aperture $14.7 \mathrm{~mm}$., breadth of aperture $10.8 \mathrm{~mm}$. (paratype specimen).

Height $6.5 \mathrm{~mm}$., length of aperture $14.5 \mathrm{~mm}$, breadth of aperture $9.9 \mathrm{~mm}$. (paratype specimen).

Height $8.1 \mathrm{~mm}$., length of aperture $16.7 \mathrm{~mm}$, breadth of aperture $11.9 \mathrm{~mm}$. (paratype specimen).

Height $6.7 \mathrm{~mm}$., length of aperture $13.6 \mathrm{~mm}$., breadth of aperture $9.5 \mathrm{~mm}$. (examined specimen collected from Moeshima in the Kagoshima Bay, Kyushu).

Type locality: Tosa Bay, Shikoku (about 70 fathoms).

Fossil occurrence: Moeshima in the Kagoshima Bay, Kyushu (Pleistocene).

Remarks: this new species resembles Emarginula hosoyai, but may be distinguished from the latter in having the larger and lower conical shell with 
the radial colour markings. Emarginula maculata SowERBY is somewhat close to the young specimen of this species.

\section{Emarginula maculata A. ADAMS}

1863 Emarginula maculata A. ADAMs, Thes, Conch., 3. p. 215, pl. 246, figs. 31, 32.

1873 Emarginula maculata SOWERBY, Conch, Icon., 19, Emarginula, pl. 5, fig. 32.

1890 Emarginula maculata PILSBRY, Man. Conch., 12, p. 263, pl. 28, fig. 4.

1915 Emarginula maculata THIELE, Conch. Cab., 2 (4a), p. 95, pl. 11, figs. 18, 19.

Height $3.4 \mathrm{~mm}$., length of aperture $7.5 \mathrm{~mm}$., breadth of aperture $5.6 \mathrm{~mm}$. (after Sowerby's figures).

Type locality: Goto Islands, Japan.

\section{Emarginula japonica SowERBY}

1863 Emarginula japonica SOWERBY, Thes. Conch., 3, p. 216, pl. 246, figs. 43, 44.

1873 Emarginula japonica SOWERBY, Conch. Icon., 19, Emarginula, pl. 8, fig. 59.

1890 Emarginula japonica PILSBRY, Man. Conch., 12, p. 264, pl. 28, fig. 18.

1915 Emarginula japonica THIELE, Conch. Cab., 2 (4a), p. 94, pl. 11, figs. 14, 15.

Height $5.2 \mathrm{~mm}$., length of aperture $10.2 \mathrm{~mm}$, breadth of aperture $7.0 \mathrm{~mm}$. (after A. Adams' figures).

Type locality : Japan.

Remarks: This is a small purplish shell and has never been rediscovered since.

\section{Emarginula concinna A. ADAMS}

(P1. II, Figs. 10, 15)

1852 Emarginula concinna A. ADAMs, Proc. Zool. Soc. London, 19, p. 85.

1863 Emarginula concinua A. ADAMs, Thes. Conch., 3, p. 212, pl. 246, figs. 34, 39, 40.

1873 Emarginula concinua SOWERBY, Conch, Icon., 19, Emarginula, pl. 2, fig. 13.

1890 Emarginula concinna PILSBRY, Man. Conch., 12, p. 257, pl. 28, figs. 5, 6.

1909 Emarginula concinna CONTURIER, Jour. be Conchyl., 55, p. 172.

1913 Emarginula concinna Thiele, Conch. Cab., 2 (4a), p. 61, pl. 7, fig. 10.

Height $2.6 \mathrm{~mm}$., length of aperture $7.3 \mathrm{~mm}$., breadth of aperture $4.7 \mathrm{~mm}$. (figured specimen collected by Mr. Akibumi Teramachi from Ryukyu group).

Height $2.4 \mathrm{~mm}$., length of aperture $6.7 \mathrm{~mm}$, breadth of aperture $4.1 \mathrm{~mm}$. (examined specimen from Ryukyu group).

Type locality: Unknown.

Distribution: Ryukyu group and Honshu. 
Emarginula compta n. sp.

(P1. II, Figs. 11, 12)

Shell small, reaching $7 \mathrm{~mm}$. in length of shell, height being about 60 to $65 \%$ of the length; ashy white, maculated with four square blackish patches, one in front of the apex and one below the summit, the other two on both side slopes, but sometimes lacking partly or all of them; apical whorl smooth and polished, bent a little below the summit and reduced to a small hook, situated at the posterior end; anterior slope strongly convex and posterior slope straight; anal fasciole narrow and with numerous arched transverse lamellae; fissure also narrow and rather short, one-fifth of the length of the anterior slope; sculpture consists of about 30 primary ribs radiating from the apex to the margin, secondary ribs alternate with them; the distantly placed concentric cords cross the surface of the shell, forming nodules where they intersect the ribs dividing the spaces between the ribs into square pits; in addition to them numerous densely set concentric threads cover all over the surface of the shell, forming the delicate texture; margin crenulated.

Height $4.3 \mathrm{~mm}$., length of aperture $7.1 \mathrm{~mm}$., breadth of aperture. $4.8 \mathrm{~mm}$. (the largest paratype specimen collected by Mr. Akibumi Teramacm from Ryukyu group).

Height $2.8 \mathrm{~mm}$., length of aperture $4.8 \mathrm{~mm}$., breadth of aperture $3.3 \mathrm{~mm}$. (figured type specimen).

Height $3.5 \mathrm{~mm}$., length of aperture $6.1 \mathrm{~mm}$, breadth of aperture $4.4 \mathrm{~mm}$. (paratype specimen).

Type locality: Okinawa, Ryukyu group.

Remarks: This new species is very peculiar in the coloration of the shell and differs distinctly from any other species.

\section{Emarginula scabriuscula A. ADAMS}

1852 Emarginula scabriuscula A. ADAMS. Proc. Zool. Soc. London, 19, p. 83.

1863 Emarginula scabriuscula A. A. DAMS, Thes. Conch., 3, p. 213, pl. 246. fig. 36.

1873 Emarginula scabriuscula SOWERBY, Conch. Icon., 19, Emarginula, pl. 5, fig. 30.

1890 Emarginula scabriuscula PILSBRY, Man. Conch., 12, p. 268, pl. 28, fig̀. 31.

1915 Emarginula scabriuscula THIELE, Conch. Cab., 2 (4a), p. 82, pl. 10, figs. 3, 4.

Height $3.1 \mathrm{~mm}$, length of aperture $7.3 \mathrm{~mm}$, breadth of aperture $5.0 \mathrm{~mm}$. (after A. ADAMs' figures).

Type locality: Unknown.

Remarks: This species was reported as occurring in Japan by A. ADAms, but has never been rediscovered from our seas. 


\section{Emarginula imaizumi DALL}

1926 Emarginula imaizumi DALL, Proc. Biol. Soc. Washington, 39, p. 65.

1926 Emarginula (imaizumi var ?) imella DALL, Proc. Biol. Soc. Washington, 39, p. 65.

Height $4 \mathrm{~mm}$., length of aperture $13 \mathrm{~mm}$., breadth of aperture $8.6 \mathrm{~mm}$.

Type locality: Imaizumi, Kagoshima Bay, Kyushu.

\section{Emarginula punctata A. ADAMS}

1852 Emarginula punctata A. ADAMS, Proc. Zool. Soc. London, 19, p. 84.

1863 Emarginula punctata A. ADAMS Thes. Conch, 3, p. 215, pl. 246, figs. 29, 30.

1873 Emarginula punctata SOWEBY, Conch. Icon., 19, Emarginula, pl. 5, fig. 31.

1890 Emarginula punctata PILSBRY, Man. Conch., 12, p. 263, pl. 28, fig. 33.

1915 Emarginula punctata THIELE, Conch. Cab., 2 (4a), p. 93, pl. 11, figs, 11, 12, 13.

Height $3.7 \mathrm{~mm}$., length of aperture $6.3 \mathrm{~mm}$, breadth of aperture $5.0 \mathrm{~mm}$. (examined specimen collected from Shirahama, Wakayama Pref., Honshu).

Height $3.5 \mathrm{~mm}$., length of aperture $5.8 \mathrm{~mm}$., breadth of aperture $4.7 \mathrm{~mm}$. (examined specimen collected by Mr. Akibumi Teramachi from the Ryukyu group).

Type 1ocality: San Nicholas, Island of Zebu, Philippines (under stones in the lower water).

Distribution: Philippines; Formosa; Ryukyu and Amami groups: Kyushu; Shikoku and Honshu.

\section{Emarginula altilis GoULD}

1859 Emarginula (Clypidina) altilis GouLD, Proc. Boston Soc. Nat. Hist., 7, p. 162.

Height $4 \mathrm{~mm}$., length of aperture $5 \mathrm{~mm}$., breadth of aperture $4 \mathrm{~mm}$.

Type locality: Kagoshima Bay (10 fathoms in depth).

Remarks: This species somewhat resembles Emarginula punctata A. Adams.

\section{Emarginula variegata A. ADAMS}

1852 Emarginula variegata A. ADAMS, Proc. Zool. Soc. London, 19, p. 84.

1863 Emarginula variegala A. ADAMS Thes. Conch., 3, p. 215, pl. 245, figs. 9, 10.

1873 Emarginula variegata SoWERBY, Conch. Icon., 19, Emarginula, pl, 4, fig. 22.

1890 Emarginula variegata PILSBRY, Man. Conch., 12, p. 263, pl. 28, fig. 12.

1915 Emarginula variegata THIELE, Conch. Cab., 2 (4a), p. 92, pl. 11, figs. 5, 6.

1941 Emarginula fuliginea KURODA, Mem. Fac. Sci. Agr. Taihoku Imp. Univ., 22 (4), p. 72 , pl. 13 figs. 1,2 ,

Height $4.9 \mathrm{~mm}$., length of aperture $10.0 \mathrm{~mm}$., breadth of aperture $7.6 \mathrm{~mm}$. 
(examined specimen collected from Tanegashima, south of Kyushu).

Height $4.8 \mathrm{~mm}$., length of aperture $9.8 \mathrm{~mm}$., breadth of aperture $7.3 \mathrm{~mm}$. (examined specimen from Tanegashima).

Type locality: Philippines.

Distribution: East Indies; Philippines ; Formosa ; Ryukyu and Amami groups and Kyushu.

\section{Emarginula pileata GoULD}

1859 Emarginula pileata Gould, Proc. Boston Soc. Nat. Hist., 7, p. 162.

Height $4 \mathrm{~mm}$. length of aperture $5 \mathrm{~mm}$., breadth of aperture $4 \mathrm{~mm}$.

Type locality: Loo Choo (=Ryukyu).

\section{Genus Laeviemarginula HABE 1953}

1953 Laeviemarginula HABE, Illust. Cat. Jap. Shells, 23, p. 183.

Type species : Laeviemarginula membranacea HABE (monotypy).

\section{Laeviemarginula membranacea $\mathrm{HABE}$}

(Pl. II, Figs. 16, 17)

1953 Laeviemarginula membranacea HABE, Illust. Cat. Jap. Shells, 23, p. 183.

Height $4.7 \mathrm{~mm}$, length of aperture $19.8 \mathrm{~mm}$., breadth of aperture $13.6 \mathrm{~mm}$. (figured type specimen).

Type locality : Okinawa, Ryukyu group.

\section{Genus Emarginella PILSBRY 1890}

1890 Emarginella PILSBRY, Man. Conch., 12, p. 269.

Type species: Emarginula cuvieri Audourn (monotypy).

\section{Emarginella incisula (A. ADAMS)}

1952 Emarginula incisula A. ADAMS, Proc. Zool. Soc. London, 19, p. 84,

1863 Emarginula incisula A. ADAMs, Thes. Conch., 3, p. 211, pl. 245, fig. 2.

1873 Emarginula incisula SOWERBY, Conch. Icon., 19, Emarginula, pl. 3, fig. 18.

1890 Emarginula incisula PILSBRY, Man. Conch., 12, p. 265, pl. 28, fig. 1.

1905 Emarginula incisula HEdLEY, Proc. Linn. Soc. N. S. Wales, 30, p. 521.

1915 Emarginula (Emarginella) incisula THIELE, Conch. Cab., 2 (4a), p. 98, pl. 11, fig. 26.

Height $4.6 \mathrm{~mm}$, length of aperture $15.8 \mathrm{~mm}$., breadth of aperture $9.0 \mathrm{~mm}$. (examined specimen collected by Dr. Tokubei Kuroda from Amami O-Shima). 
Type locality: Unknown.

Distribution : East Indies; Amami group.

\section{Emarginella planulata (A. ADAMS)}

(Pl. II, Figs. 24, 26)

1852 Emarginula planulata A. ADAMS, Proc. Zool. Soc. London, 19, p. 86.

1863 Emargiuula planulata A. ADAMS, Thes. Conch., 3, p. 211, pl. 245, fig. 1.

1873 Emarginula planulata SoWERBY, Conch. Icon., 19, Emarginula, pl. 3, fig. 20.

1890 Emarginula planulata PILSBRY, Man. Conch., 12, p. 264, pl. 28, fig. 15.

1915 Emarginula (Emarginella) planulata THIELE, Conch. Cab., 2 (4a), p. 28, pl. 11. fig. 27.

Height $9.7 \mathrm{~mm}$., length of aperture $25.3 \mathrm{~mm}$, breadth of aperture $17.0 \mathrm{~mm}$. (figured specimen collected from Wakayama Pref., Honshu by Mr. Akibumi Teramachi).

Height $9.5 \mathrm{~mm}$., length of aperture $30.1 \mathrm{~mm}$, breadth of aperture $20.2 \mathrm{~mm}$. (examined specimen collected from Hirado, Nagasaki Pref., Kyushu by Dr. Tokubei KuRODA).

Type locality: Singapore (coarse sand and shells, 7 fathoms in depth).

Distribution: Singapore; Philippines; Kyushu and Honshu.

\section{Emarginella eximia (A. ADAMS)}

$$
\text { (Pl. II, Figs. 3, 4) }
$$

1852 Emarginula eximia A. ADAMS, Proc. Zool. Soc. London, 19, p. 86.

1863 Emarginula eximia A. ADAMS, Thes. Conch., 3, p. 212, pl. 246, fig 63.

1890 Emarginula eximia PILSBRY, Man. Conch., 12, p. 267, pl. 28, fig. 26.

1915 Emarginula eximia THIELE, Conch. Cab., 2 (4a), p. 89, pl. 10, figs. 22, 23.

Height $3.3 \mathrm{~mm}$., length of aperture $10.5 \mathrm{~mm}$., breadth of aperture $7.3 \mathrm{~mm}$. (figured specimen collected from the Ryukyu group by Mr. Akibumi Teramachi).

Height $3.1 \mathrm{~mm}$., length of aperture $10.7 \mathrm{~mm}$., breadth of aperture $7.1 \mathrm{~mm}$. (examined specimen collected from the Ryukyu group).

Type locality: San Nicholas, Island of Zebu, Philippines (under stones in the lower water).

Distribution: Philippines and Ryukyu group.

\section{Emarginella okinawaensis n. sp.}

(Pl. II, Figs. 5, 6)

Shell white, depressed, not attaining $13 \mathrm{~mm}$. in length, the height being about 
$35 \sim 45 \%$ in the length of shell; apical whorls are turned backwards and downward and is not hooked; that place about at the middle of shell; anterior slope slightly concave and posterior slope straight or a little convex; anal fasciole narrow and raised; fissure very short, about one-sixth the length of the anterior slope; the primary radial ribs are strong, about nine in number; the secondary ribs intercalated between them; concentric cords are very strong and place distantly on the shell where they give the large excavated square mesh; the crenulations of the margin caused by the primary ribs being particulary large.

Height $4.5 \mathrm{~mm}$, length of aperture $12.9 \mathrm{~mm}$, breadth of aperture $10.1 \mathrm{~mm}$. (figured type specimen).

Height $4.5 \mathrm{~mm}$., length of aperture $11.7 \mathrm{~mm}$, breadth of aperture $9.6 \mathrm{~mm}$. (paratype specimen).

Height $5.2 \mathrm{~mm}$., length of aperture $11.8 \mathrm{~mm}$, breadth of aperture $9.0 \mathrm{~mm}$. (paratype specimen).

Height $3.9 \mathrm{~mm}$., length of aperture $10.9 \mathrm{~mm}$, breadth of aperture $8.6 \mathrm{~mm}$. (paratype specimen).

Type locality: Okinawa, Ryukyu group.

Remarks: This new species approaches to Emarginella sculptilis A. AdAms from the Philippines in the general appearance, but has no colour spots between each of the large ribs on the surface of the shell. Emarginella crassilabrum A. Adams is another allied one.

\section{Tugali GRAY 1843}

1843 Tugali GRAY. Dieffenbach Travel in New Zealand, 2, p. 240.

1857 Tugalia GraY, Guide Moll. Brit. Mus., p. 163.

Type species: Tugali elegans GraY (monotypy).

\section{Tugali decussata A. ADAMS}

(P1. Ir, Figs. 25, 29)

1852 Tugali decussata A. ADAMS, Proc. Zool. Soc. London, 19, p. 89.

1863 Tugalia decussata A. ADAMs, Thes. Conch., 3, p. 222, pl. 249, fig. 12.

1870 Tugalia decussata ReEve, Conch. Icon., 17, Tugalia, sp. 6.

1890 Subemarginula decussata PILSBRY, Man. Conch., 12, p. 286, pl. 43, figs. 88.

1915 Emarginula (Tugalia) decussata THIELE, Conch. Cab., 2 (4a), p. 103, pl. 12. fig. 13.

1915 Emarginula angustata THIELE, $l . c$, p. 108, pl. 15, figs. 27, 28.

1951 Tugali decussata ls. TAKI, HiRASE's Handb. Illust. Shells, pl. 63, fig. 5.

Height $5.0 \mathrm{~mm}$., length of aperture $13.3 \mathrm{~mm}$., breadth of aperture $9.3 \mathrm{~mm}$. (examined specimen collected from Shirahama, Wakayama Pref., Honshu). 
Height $4.6 \mathrm{~mm}$., length of aperture $14.3 \mathrm{~mm}$, breadth of aperture $9.9 \mathrm{~mm}$. (figured specimen collected from the same).

Type 1ocality: Philippine islands.

Distribution: Philippines; Kyushu; Shikoku and Honshu.

\section{Tugali scutellaris A. ADAMS}

(Pl. II, Fig. 1)

1852 Tugali scutellaris A. ADAMs, Proc. Zool. Soc. London, 19, p. 89.

1863 Tugalia scutellaris A. ADAMs, Thes. Conch., 3, p. 222, pl. 14, figs. 8, 9.

1870 Tugalia scutellaris REEve, Conch. Icon., 17. Tugalia, fig. 1.

1890 Subemarginula (Tugalia) scutellaris PILSBRY, Man. Conch., 12, p. 286, pl. 43, figs. 81,82 .

1915 Emarginula (Tugalia) scutellaris THIELE, Conch. Cab., 2 (4a), p. 104, pl. 12, fig. 14.

Height $3.3 \mathrm{~mm}$., length of aperture $14.8 \mathrm{~mm}$, breadth of aperture $10.5 \mathrm{~mm}$. (figured specimen collected by Mr. A. Teramachi from Wakayama Pref., Honshu).

Type locality : Bais, Philippines.

Distribution: Philippines and Wakayama Pref., Honshu.

\section{Tugali vadososinuata (YoKoYAMA)}

$$
\text { (P1. Ir, Figs. 35, 36) }
$$

1922 Emarginula vadososinuata YoKoYAMA, Jour. Coll. Sci. Imp. Univ: Tokyo, 44 (1), p. 117, pl. 6, fig. 5 .

1939 Tugalia vadososinuata TrBA, Venus, 9, p. 44 with textfig.

Height $35.5 \mathrm{~mm}$., length of aperture $27.1 \mathrm{~mm}$., breadth of aperture $12.9 \mathrm{~mm}$. (figured specimen collected from off Iwate Pref., Honshu by Mr. Ryosuke KAWAMURA).

Type locality: Shito, Ichihara gun, Chiba Pref., Honshu. (fossil).

Distribution: Hokkaido and Northern Honshu.

\section{Tugali (?) gigas (v. MARTENS)}

(P1. II, Figs. 34)

1881 Submarginula gigas v. MARTEnS, Conch. Mittheil., 2, p. 103, pl. 19.

1890 Subemarginula gigas. PILSBRY, Man. Conch., 12, p. 286.

1915 Emarginula (T'ugalia) gigas THIELE, Conch. Cab., 2 (4a), p. 101, pl. 12, figs. 81, 8-10.

1929 Tugalia gigas TOBA, Venus, 1 (5), p. 194.

1947 Tugali gigas HIRASE et KURODA, Illust. Encycl. Fauna Japan (rev. ed.), p. 1193, fig. 3400 .

1951 Tugali gigas Is. TAKI, HIRASE's Handb. Illust. Shells, pl. 63, fig. 4. 
Height $25.6 \mathrm{~mm}$, length of aperture $93 \mathrm{~mm}$., breadth of aparture $58.4 \mathrm{~mm}$., (examined specimen collected from Iwate Pref., Honshu).

Height $21.6 \mathrm{~mm}$, length of aperture $86.5 \mathrm{~mm}$., breadth of aperture $52.9 \mathrm{~mm}$. (figured specimen collected from Iwate Pref., Honshu).

Type locality: Northern Honshu.

Distribution: Northern Honshu and Hokkaido.

\section{Genus Tugalina HABE 1953}

1953 Tugalina HABF, Illust. Cat. Jap. Shells, 23, p. 183.

Type species: Tugalina radiata $\mathrm{HABE}$ (monotypy).

\section{Tugalina radiata HABE}

(P1. II, Fig. 2)

1953 Tugalina radiata HABE, Illust. Cat Jap. Shells, 23, p. 183.

Height $1.7 \mathrm{~mm}$, length of aperture $14.5 \mathrm{~mm}$., breadth of aperture $10.2 \mathrm{~mm}$. (figured type specimen).

Height $2.0 \mathrm{~mm}$, length of aperture $10.5 \mathrm{~mm}$., breadth of aperture $8.0 \mathrm{~mm}$. (paratype specimen).

Type locality: Okinawa, Ryukyu group.

\section{Genus Montfortula Iredale 1915}

1915 Montfortula Iredale, Trans, Proc. New Zealand Inst., 47, p. 433.

Type species: Emarginula rugosa QuoY et GAIMARD (original designation).

Montfortula pulchra (A. A.DAMS)

(Pl. II, Fig. 7)

1852 Emarginula pulchra A. ADAMS, Proc. Zool. Soc. London, 19, p. 85.

1863 Emarginula pulchra A. ADAMs, Thes, Conch., 3 p. 219, pl. 246, figs. 50, 51.

1860 Emarginula picta DUNiKER, Mal. B1., 6 p. 226.

1861 Emarginula picta DuNǨER, Moll. Jap., p. 23, pl. 3, fig. 5.

1874 Emarginula pulchra SOWERBY, Conch. ICon., 9, Emarginula, pl. 2, fig. 7.

1890 Subemarginula pulchra PilsBRY, Man. Conch., 12. p. 282, pl. 28, fig. 28.

1916 Clypidina pulchra THIELE, Conch. Cab., 2 (4a), p. 132, pl. 15, fig. 11.

1926 Subemarginula cratitioides YoKоYAMA, Jour. Coll. Sci. Imp. Univ. Tokyo, 45, p. 36, pl. 2, fig. 10 .

1945 Clypiatina (Montfortula) pulchra HABE, Jap. Jour. Malac., 14, pl. 1, fig. 1.

1951 Clypidina picta Is. TAKI, HIRAsE's Handb. Illust. Shells, pl. 63, fig. 3. 
Height $6.3 \mathrm{~mm}$, length of aperture $13 \mathrm{~mm}$, breadth of aperture $9.6 \mathrm{~mm}$. (figured specimen collected from Shirahama, Wakayama Pref., Honshu).

Height $8.1 \mathrm{~mm}$., length of aperture $13.4 \mathrm{~mm}$., breadth of aperture $9.6 \mathrm{~mm}$. (examined specimen collected from Kochi Perf., Shikoku).

Type locality: Isle of Camaguan, Philippines (on exposed rocks, lower water).

Distribution: Philippines; Kyushu; Shikoku and Honshu.

Montfortula (pulchra var.) polygonalis (A. ADAMS)

(P1. II, Figs. 8, 9)

1952 Emarginula polygonalis A. ADAMS, Proc. Zool. Soc. London, 19, p. 91.

1862 Emarginula (Clypidina) textilis GoULD, Proc. Boston Soc. Nat. Hist., 7, p. 163.

1863 Emarginula polygonalis A. ADAMS, Thes. Conch., 3, p. 217, pl. 247, fig, 78; pl. 248, fig. 90 .

1873 Emarginula polygonalis SoWERBY, Conch. Icon., 19, Emarginula, pl. 2, fig. 6.

1890 Subemarginula (Clypidina) polygonalis PILSBRY, Man. Conch., 12, p. 281, p1. 29, figs. 34,35 .

1916 Hemitoma polygonalis THIele, Conch. Cab., 2 (4a), p. 117, pl. 15, fig. 5.

Height $7.3 \mathrm{~mm}$., length of aperture $13.2 \mathrm{~mm}$, breadth of aperture $9.6 \mathrm{~mm}$. (figured specimen collected from Tokunoshima, Amami group).

Type locality: Catanuan, Philippines.

Distribution: Philippines, Ryukyu and Amami groups.

Genus Montfortia RÉcLuz 1843

1843 Montfortia RÊCLUZ, Rev. Zool., p. 259.

Type species: Emarginula australis QuOY et GAIMARD (designated by Iredale 1915).

\section{Montfortia oldhamiana (NEVILL)}

(P1. II, Figs. 18, 19)

1869 Emarginula oldhamiana NEVILL, Jour. Asist. Soc. Bengal, 38, p. 162, pl. 17. fig. 17.

1873 Emarginula oldhamiana SoWERBY, Conch. Icon., 19, Emarginula, fig. 69.

1890 Subemarginula oldhamiana PILSBRY, Man. Conch., 12, p. 277, pl. 41, figs. 32, 33.

1916 Hemitoma oldhamiana THIELE, Conch. Icon, 2 (4a), p. 117, pl. 13, fig. 18.

Height $8.7 \mathrm{~mm}$., length of aperture $14 \mathrm{~mm}$., breadth of aperture $9.5 \mathrm{~mm}$. (figured specimen collected from Shirahama, Wakayama Pref., Honshu).

Type locality : Ceylon.

Distribution: Ceylon and Wakayama Pref., Honshu. 


\section{Subgenus Monfortista IREDALE 1919}

1929 Montfortista IREdale, Mem. Queensland Mus., 9 (3), p. 269.

Type species: Montfortia excentrica IREDALE (original designation).

\section{Montfortia (Montfortista) panhi (QUOY et GAIMA.RD)}

(P1. Ir, Figs. 27, 28)

1834 Emarginula panhi QUOY et GAIMARD, Voy. de 1' Astrol., p. 327, pl. 68, figs. 7. 8. 1850 Emarginula clathrata A. ADAMS et REEVE, Voy. Samarang, Moll., p. 69, pl. 11, fig. 6. 1852 Subemarginula panhiensis ADAMS, Proc. Zool. Soc. London, 19, p. 90.

1863 Emarginula panhiensis SOWERBY, Thes. Conch., 3, p. 218, pl. 247, figs. 73, 74, 75.

1873 Emarginula panhiensis SOWERBY, Conch. Icon., 19, Emarginula, pl. 6, fig. 43.

1890 Emarginula tricarinata PILSBRY, Man. Conch., 12, p. 277, pl. 29, figs. 73-79.

1916 Hemitoma panhiensis THIELE, Conch. Cab., 2 (4a), p. 116, pl. 13, figs. 12, 13.

1947 Hemitoma (Montfortista) panhi HIRASE et KURODA, Illust. Encycl. Fauna Japan (rev. ed), p. 1194, fig. 3402 .

1951 Hemitoma panhi Is. TAKI, HIRASE's Handb. Illust. Shells, pl. 63, fig. 2.

Height $11.4 \mathrm{~mm}$., length of aperture $18.3 \mathrm{~mm}$, breadth of aperture $13 \mathrm{~mm}$. (the largest examined specimen collected from Ryukyu group by $\mathrm{Mr}$. A. TERAMACHI).

Height $9.8 \mathrm{~mm}$, length of aperture $16.1 \mathrm{~mm}$, breadth of aperture $8.7 \mathrm{~mm}$. (examined specimen from the same locality).

Height $8.4 \mathrm{~mm}$, length of aperture $14.6 \mathrm{~mm}$, breadth of aperture $8.5 \mathrm{~mm}$. (figured specimen from the same locality).

Type locality: Tonga Tabu, South Pacific Ocean.

Distribution: Tonga Tabu; Palao 1sland; Philippines; Ryukyu and Amami groups. 


\section{EXPLANATION OF PLATE II}

(all figures unequally magnified)

Fig.1. Tugali scutellaris A. ADAMs.

2. Tugalina radiata HABE.

3,4. Emarginella eximia (A. ADAMs).

5,6. Emarginella okinawaensis n. sp. (type specimen).

7. Montfortula pulchra (A. ADAMs).

8,9. Montfortula (pulchra var.) polygonalis (A. ADAMs).

10,15. Emargimula concinna A. ADAMs.

11,12. Emarginula compta n. sp. (type specimen).

13,20. Emarginula hataii n. sp. (type specimen).

14,23. Emarginula teramachii n. sp. (type specimen).

16,17. Laeviemargimula membranacea HABE (type specimen).

18, 19. Montfortia oldhamiana (NEvilL).

21,22. Emarginula fragilis (YокоYAMA).

24, 26. Emarginella planulata (A. ADAMs).

25,29. Tugali decussata (A. ADAMs).

27, 28. Montfortia (Montfortista) panhi (Quoy et GAIMARD).

30,31. Emarginula regia n. sp. (type specimen).

32,33. Emargimula fujitai n. sp. (type specimen).

34. Tugali (?) gigas (v. MARtens).

35,36 . Tugali vadososimuata (Yокочама). 
Publ. Seto Mar. Biol. Lab., III (1), 1953.
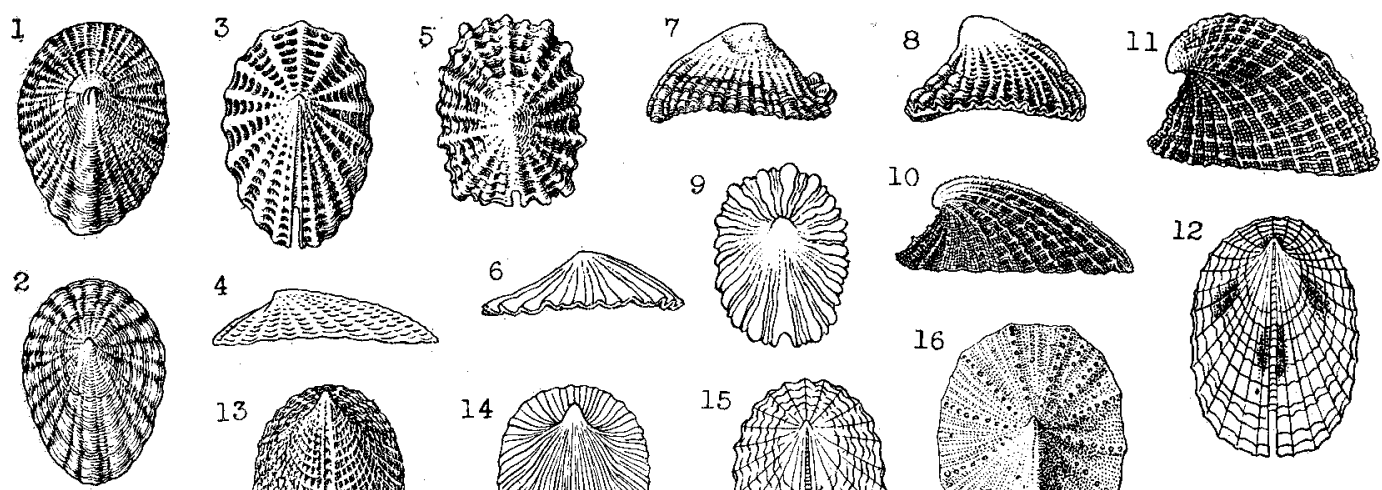

4 6
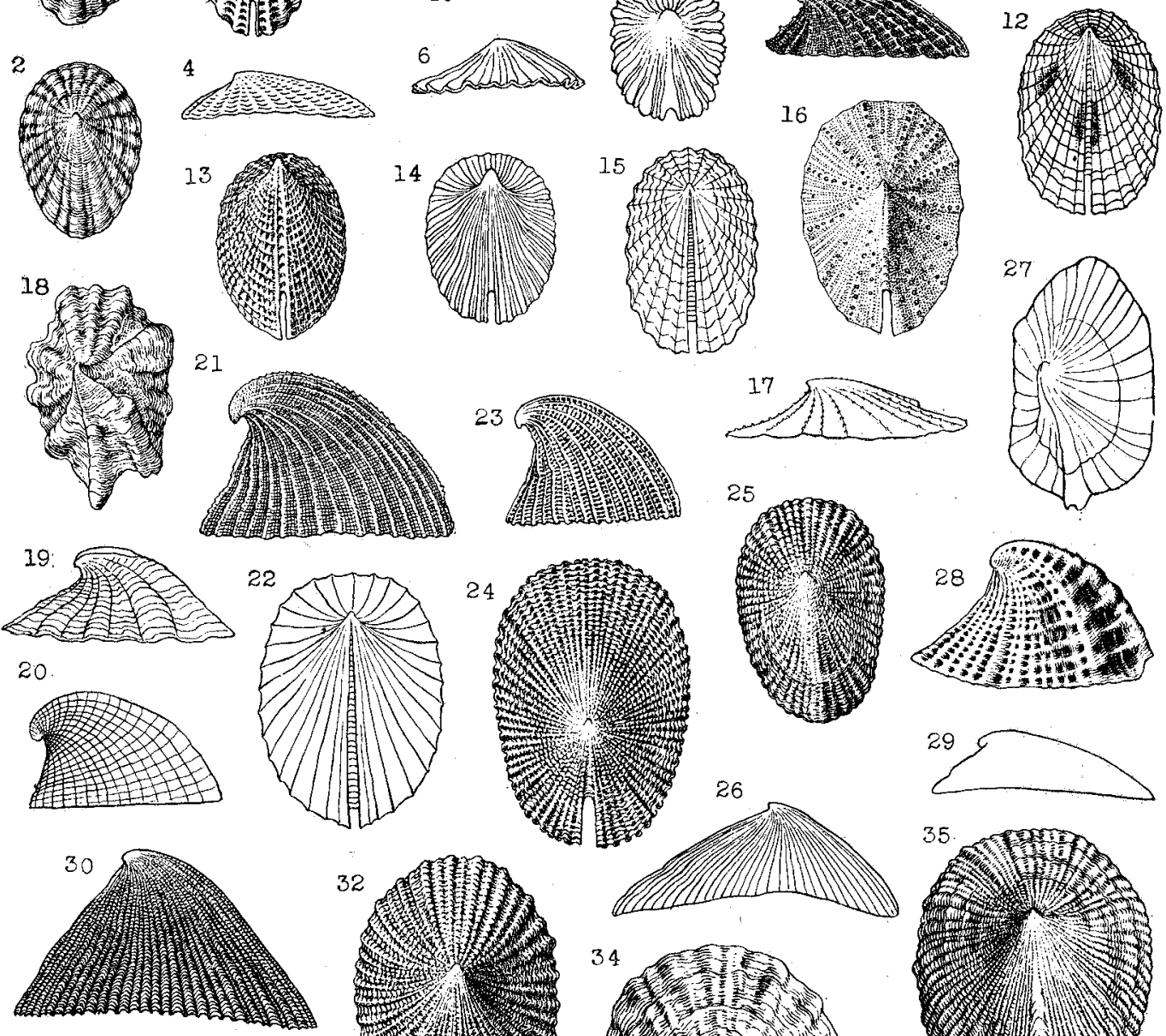

32
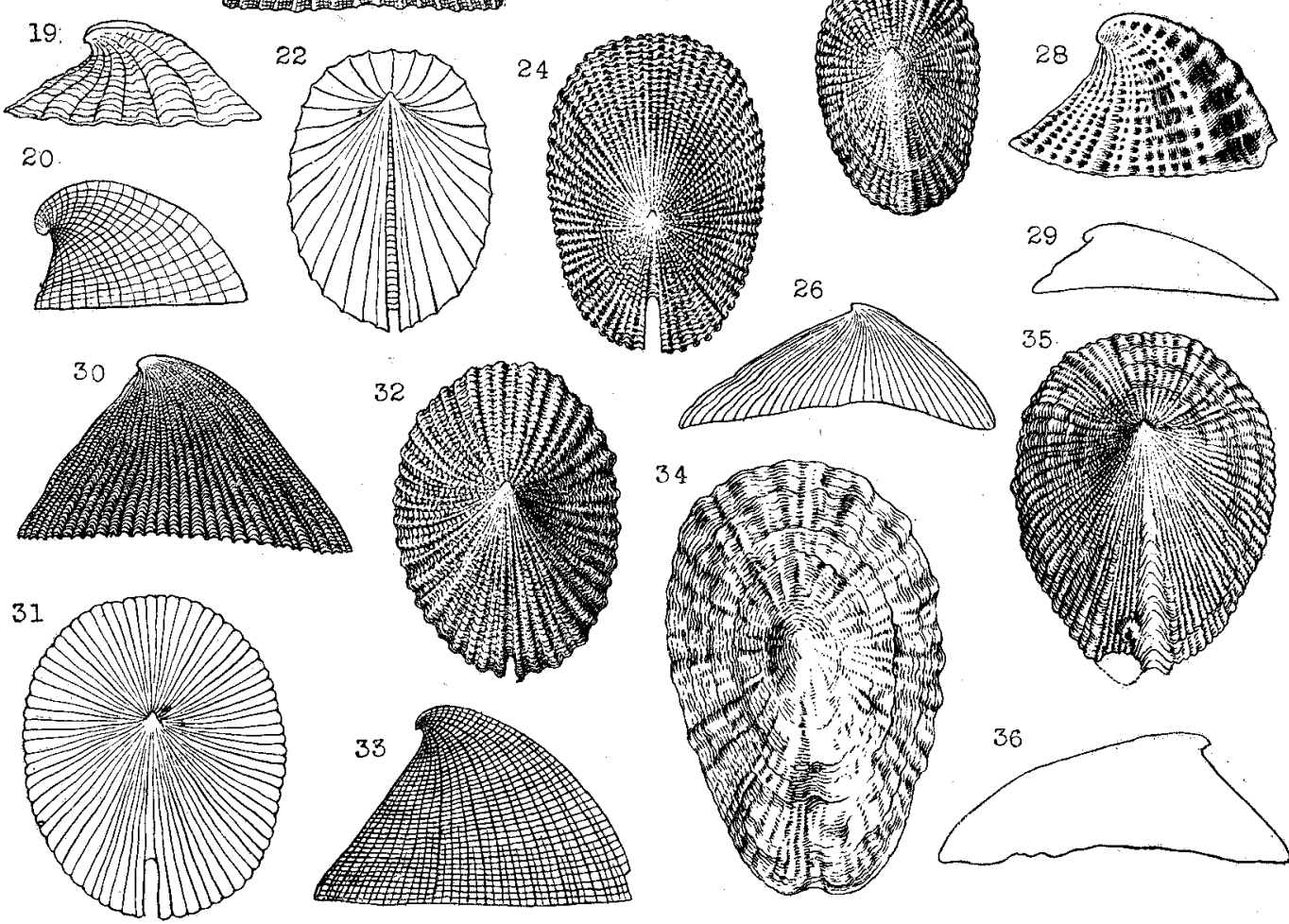

T. Habe: Fissurellidae In Japan (2). 